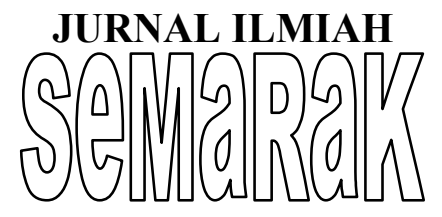

P-ISSN 2615-6849, E-ISSN 2622-3686

Jurnal Semarak,Vol. 1,No.3,Oktober 2018 , Hal (20-38)

@Prodi Manajemen Fakultas Ekonomi Universitas Pamulang

\title{
PENGARUH ATRIBUT PRODUK, PROMOSI DAN VARIETY SEEKING TERHADAP BRAND SWITCHING
}

\author{
(Studi Kasus Kartu Perdana INDOSAT Di Serpong Tangerang Selatan)
}

\author{
Agung Tri Putranto, S.T., M.M. \\ Staf Pengajar Fakultas Ekonomi Universitas Pamulang \\ Email: agung.tputranto@gmail.com
}

\begin{abstract}
ABSTRAK
Penelitian ini memiliki tujuan untuk menganalisis pengaruh positif secara parsial atribut produk, promosi dan Variety Seeking terhadap brand switching, untuk menganalisis pengaruh positif secara simultan atribut produk, promosi dan Variety Seeking terhadap brand switching, untuk menganalisis variabel independen mana yang paling dominan mempengaruhi variabel dependen. Data yang digunakan dalam penelitian ini menggunakan data primer yang diperoleh dari jawaban dari responden yang pernah menggunakan kartu perdana Indosat yang diberikan kuesioner. Pemilihan sampel pada penelitian ini adalah semua pengguna kartu perdana Indosat. Hasil penelitian ini menunjukkan bahwa terdapat pengaruh secara simultan pada variabel atribut produk, promosi dan variety seeking terhadap brand switching. Hasil penelitian ini juga menunjukkan variabel produk, promosi dan variety seeking berpengaruh signifikan secara parsial terhadap brand switching. Pada uji determinasi terdapat pengaruh sebesar 63,1\% yang mempengaruhi brand switching yang dijelaskan oleh variabel atribut produk, promosi dan variety seeking, sedangkan sisanya 36,9\% dipengaruhi oleh variabel lain dan tidak termasuk kedalam analisis regresi ini.
\end{abstract}

Kata kunci: atribut produk, promosi, variety seeking, brand switching

\begin{abstract}
This study aims to analyze the effect of a partial positive attributes of products, promotions and Variety Seeking to brand switching, to analyze simultaneously the positive effect of product attributes, and Variety Seeking promotions on brand switching, to analyze the independent variables are the most dominant influence on the dependent variable. The data used in this study using primary data obtained from the answers of the respondents who had used theIndosat card given questionnaires. The sample in this study were all card users Indosat. The results of this study indicate that there is a simultaneous effect on the variable product attributes, variety seeking and promotion on brand switching. The results also showed variable products, promotions and variety seeking significant effect partially on brand switching. There is an influence on the determination test by 63,1\% affecting brand switching is explained by the variable product attributes promotions and variety seeking, while the remaining 36,9\% is influenced by other variables and are not included into the regression analysis.
\end{abstract}

Keywords: product attributes, promotions, variety seeking, brand switching 


\section{PENDAHULUAN}

\section{A. Latar Belakang}

Perkembangan perniagaan kad selular kebelakangan ini telah menunjukkan gejala, iaitu peningkatan dan pelbagai produk kad selular yang ditawarkan oleh syarikat kad selular serta perkembangan produk telefon bimbit yang semakin cepat. Perkembangan pesat produk kad selular terutamanya terletak pada harga yang ditawarkan dan kemudahan. Kemudahan yang lebih lama yang disediakan oleh syarikat kad selular semakin membuat pengguna bebas memilih kad selular yang sesuai dengan keperluan mereka.

Dengan perkhidmatan yang menarik pengguna akan meningkatkan keinginan pengguna lain untuk menggunakannya. Dalam hal ini peranan pengguna sangat menentukan kelangsungan hidup suatu produk. Menurut Simamora (2004) dalam (Ribhan, 2007: 109) menjelaskan bahawa pengguna yang sering membuat pertukaran jenama dalam pembelian mereka termasuk dalam jenis tingkah laku belanja yang mencari kepelbagaian (Pelbagai Mencari Perilaku Belian). Memandangkan banyak pilihan jenama yang ditawarkan di pasaran, serta selera pengguna yang sering berubah, ia tidak jarang dalam masa yang singkat bahawa pengguna mengubah jenama dari satu jenama yang lain.

Peralihan jenama dicirikan oleh perbezaan yang signifikan antara jenama, pengguna dalam kes ini belum dapat mengenali variasi produknya. Perusahaan harus membezakan kepakaran jenama untuk menerangkan jenama (Ribhan, 2007: 109).

Dalam beralih jenama, pengguna tidak melalui peringkat kepercayaan, sikap atau tingkah laku biasa. Pengguna tidak banyak mencari maklumat mengenai jenama, tetapi penerima maklumat pasif (penangkapan maklumat). Pengguna tidak membentuk kepercayaan mereka (kepercayaan jenama), tetapi memilih jenama kerana jenama berasa biasa (kebiasaan jenama) (Ribhan, 2007: 109).

Bagi syarikat, hal yang menentukan kejayaan untuk mewujudkan loyalitas pelangan adalah tingkat kepuasan dengan kualiti yang diberikan oleh syarikat. Dengan memenuhi faktor-faktor produk, harga, promosi, dan sifat inventori produk, diharapkan dapat meminimumkan berlakunya pergeseran jenama yang dibuat oleh pelanggan.

Tingkah laku pengguna dalam pergerakan jenama yang memberi perhatian lebih kepada harga dalam membuat pembelian, menggalakkan syarikat-syarikat untuk menjalankan beberapa promosi untuk menjelaskan ciriciri produk mereka dan mengekalkan inventori produk dalam setiap saluran pengedaran sedia ada untuk mengelakkan jurang pengedaran yang kemudiannya dapat memberikan kelebihan daya saing. Keperluan pengguna untuk kad selular di Indonesia semakin meningkat. Ini seiring 
JURNAL

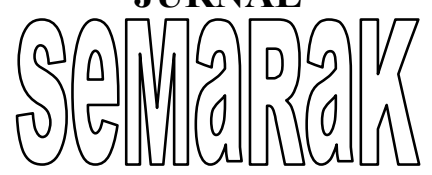

\section{P-ISSN 2615-6849 E-ISSN 2622-3686}

Semarak,Vol. 1, No.3,Oktober 2018, Hal (1-20)

@Prodi Manajemen Fakultas Ekonomi Universitas Pamulang dengan peningkatan daya beli pengguna untuk telefon bimbit. Ini menjadikan syarikat kad selular bersaing untuk menyediakan kemudahan dan kemudahan kepada pengguna untuk memastikan pengguna menggunakan kad selular yang mereka hasilkan.

Akhir-akhir ini beberapa kad selular menawarkan pelbagai kelebihan melalui pengiklanan. Pertempuran tarif untuk perkhidmatan telefon selular berlaku bersama peralihan paradigma dalam industri perkhidmatan telekomunikasi di mana pada masa lalu struktur tarif berdasarkan fungsi jarak jauh, semakin banyak jarak menjadi lebih mahal, jadi struktur tarif telefon tempatan dan jarak jauh telah berubah. akan bergantung kepada fungsi keperluan lebar jalur, lebih lebar jalur menggunakan lebih mahal. Sambungan itu tentunya perubahan dalam kandungan komunikasi ke arah multimedia dengan keperluan peruntukan kualiti dan perkhidmatan yang berbezabeza bergantung kepada kapasiti infrastruktur rangkaian telekomunikasi yang digunakan. Dalam persaingan, setiap penganjur pastinya cuba untuk membuat kejayaan untuk meningkatkan daya saing dan kepentingan pelanggan. Dalam meningkatkan daya saingnya, liputan perkhidmatan selular operator yang terus berkembang dengan kapasiti dan kualiti yang diperlukan terus dipertingkatkan mengikut piawaian yang diiktiraf dunia. Reicheld (1996) mencadangkan bahawa dari pelanggan yang berpuas hati atau sangat berpuas hati, antara $65 \%$ dan $85 \%$ akan berpindah ke produk lain (mencapai kesetiaan pelanggan, artikel pdf). Berdasarkan hasil kajian ini, dapat disimpulkan bahwa hanya memuaskan pelanggan tidak cukup untuk menjaga pelanggan setia, sementara di sisi lain pelanggan tetap bebas untuk membuat pilihan merek. (Ribhan, 2006: 94). Takrifan pemindahan jenama adalah pemindahan jenama yang dilakukan oleh pelanggan untuk setiap penggunaan (Sumarketer, Penganalisis Perniagaan Kanan, Mark Plus \& Co). Penukaran jenama dicirikan oleh penglibatan yang rendah. Pengguna adalah penerima maklumat pasif (maklumat menangkap). Atribut produk (atribut produk) adalah elemen produk yang dianggap penting oleh pengguna dan digunakan sebagai asas untuk keputusan pembelian. Atribut produk termasuk jenama, pembungkusan, jaminan (jaminan), perkhidmatan, dan sebagainya (Tjiptono, 2008: 96). Bahawa ada risiko pelanggan setia akan dipengaruhi oleh para pesaing sama ada melalui promosi produk bersaing yang dapat memberikan lebih banyak manfaat (manfaat), beragam produk bersaing. Pengiklanan atau pengiklanan adalah alat promosi yang paling banyak digunakan untuk produk pengguna. Walaupun secara tidak langsung menghasilkan pembelian, pengiklanan merupakan cara untuk membantu pemasaran yang efektif untuk 
Semarak,Vol. 1, No.3,Oktober 2018, Hal (1-20)

@Prodi Manajemen Fakultas Ekonomi Universitas Pamulang

mewujudkan komunikasi dalam upaya untuk menangani pesaing. Kewujudan iklan yang sering muncul atau dilihat oleh pengguna akan mempengaruhi pengguna untuk membuat pembelian. Dengan iklan yang sering muncul, pengguna akan membandingkan apa yang sering mereka beli dengan produk yang baru mereka beli. Sekiranya pengguna memilih produk lama, maka pengguna akan menggunakan produk lama mereka. Walau bagaimanapun, jika produk yang baru dibeli memberikan lebih banyak faedah daripada produk lama, maka pengguna akan membuat pemindahan jenama. Pelbagai Mencari Mencari variasi telah dikenalpasti sebagai faktor yang mempengaruhi pergerakan jenama.

Mencari variasi dalam kategori produk oleh konsumen adalah sikap konsumen yang ingin mencoba produk baru yang baru saja muncul di pasar atau produk lama yang belum dicoba dan memuaskan rasa ingin tahu mereka terhadap merek lain. Penemu variasi ini adalah konsumen yang memiliki perilaku mudah untuk membuat gerakan merek (Van Tjrip, 1996) dalam rustika (2010: 18). Pendapat ini sejalan dengan apa yang dikemukakan oleh Bilson Simamora (2004) yang menjelaskan bahwa "konsumen sering melakukan peralihan merek. Dalam pembelian itu termasuk dalam jenis perilaku pembelian yang mencari keragaman (Variety Seeking
Buying Behavior)". Penelitian Junaedi dan Dharmmesta (2002) juga menghasilkan pernyataan bahwa "kebutuhan untuk menemukan variasi juga mempengaruhi keputusan konsumen untuk mengubah merek".

Pengalihan merek adalah "peralihan merek yang dilakukan oleh pelanggan untuk setiap kali digunakan, tingkat pengalihan merek ini juga menunjukkan sejauh mana merek memiliki pelanggan setia (Sumarketer, Analis Bisnis Senior, MarkPlus \& Co)". Van Tjrip (1992) dalam Rustika (2010: 18) memilah dua faktor yang mempengaruhi konsumen dalam melakukan pergeseran merek, yaitu faktor internal dan eksternal. "Faktor internal adalah faktor lingkungan dari dalam diri konsumen yang dapat mempengaruhi sikap keputusan pembelian, pemilihan merek dan pergeseran merek baik secara rasional maupun emosional. Yang merupakan dimensi faktor internal konsumen adalah keinginan untuk mencari variasi (Variety Seeking), pascaKetidakpuasan konsumsi (ketidakpuasan) Faktor eksternal adalah faktor lingkungan eksternal konsumen yang dapat mempengaruhi pergerakan merek baik secara rasional dan emosional, yang dapat dijelaskan oleh iklan, promosi di toko:

Pengaruh Atribut Produk, Promosi, Variety Seeking Terhadap Brand Switching. 


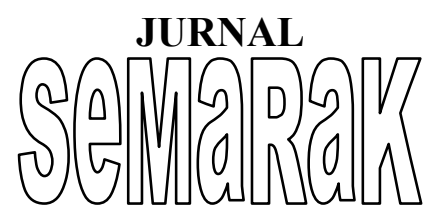

B. Rumusan Penelitian

Brand switching memiliki banyak faktor yang mempengaruhinya untuk mengetahuinya diperlukan analisa yang berdasarkan teori, maka rumusan penelitian permassalahan yanng akaan diteliiti antaara laain:

1. Apakaah terdaapat penngaruh possitif secara satu persatu attribut produk, proomosi dan Varieety Seeking terhadap pengalihan merek.

2. Apakaah terdaapat penggaruh positiif secara bersamaaan attribut produk, proomosi dan Varieety Seeking terhadap pengalihan merek.

3. Manakah variabbel inndependen yanng terdiiri darri attribut produk, proomosi dan Varieety Seeking yanng palling mempengaruhi pengalihan merek.

\section{Tujjuan Peneelitian}

Setelah dibuat suatu latar belakang dan perrumusan masallah, maka tujjuan dalaam peneelitian inni adallah sebagai berikutt:

1. Untuk menganalisiss peengaruh poositif secara satu persatu attribut produk, proomosi dan Varieety Seeking terhadap pengalihan merek.

2. Untuk menganalisis pengaruh positif secara simultan attribut produk, proomosi dan Varieety Seeking terhadap pengalihan merek.

3. Untuk menganalisis mana variabel independen yang terdiri dari attribut produk, proomosi dan Varieety Seeking yang paling mempengaruhi pengalihan merek.

\section{TINJAUAN PUSTAKA}

\section{A. Manajemen Pemasaran}

\section{Pengertian Manajemen}

Manajjemen merupakan "kosakata yang berasaal darri Prancis kuno, yaiitu manajeemen yang berarti seeni melaksanakan dan mengatur". Manajemen merupakan "suatu eleemen dassar yanng akaan selaalu daalam prosees manajeemen yanng akan menjjadi acuuan olleh manager dalaam melakssanakan kegiiatan untuuk mencapaai tuujuan".

"Manajemen berasal dari kata untuk mengelola, yang berarti mengelola, mengelola, mengelola, melaksanakan, dan mengendalikan. Manajemen adalah ilmu dan seni yang mengatur proses pemanfaatan sumber daya manusia dan sumber lain secara efektif dan efisien untuk mencapai tujuan tertentu" (Ardana, 2012:4).

Menurut Kasmir, "manajemen mengelola atau mengelola suatu kegiatan. Dalam arti sempit dikatakan bahwa manajemen mengelola perusahaan untuk mencapai tujuan melalui orang lain. Yang diatur dan dikelola adalah aset atau aset perusahaan, baik properti manusia, peralatan mesin, proses dan prosedur kerja. Aset ini perlu dikelola dengan baik, terus menerus dan berkesinambungan, jika Anda ingin 
JURNAL

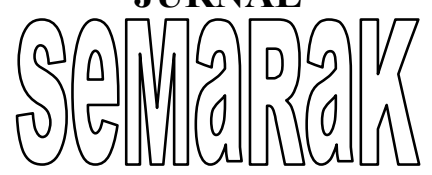

P-ISSN 2615-6849 E-ISSN 2622-3686

Semarak,Vol. 1, No.3,Oktober 2018, Hal (1-20)

@ Prodi Manajemen Fakultas Ekonomi Universitas Pamulang menghasilkan hasil yang optimal seperti yang diharapkan" (Kasmir, 2016:10).

\section{Pengertian Pemasaran}

Pemasaran mudah adalah "aktivitas pemasaran barang atau jasa umumnya kepada publik, dan terutama kepada pembeli potensial. Pemasaran dikembangkan pola yang diatur dalam sistem yang sering disebut sebagai ilmu dan juga dikembangkan oleh cara masing-masing aktor yang disebut improvisasi dan karenanya disebut seni” (Maruf, 2010:2).

"Pemasaran adalah proses mengidentifikasi dan memenuhi kebutuhan manusia dan sosial. Satu definisi dan pemasaran yang baik dan singkat adalah memenuhi kebutuhan dengan cara yang menguntungkan" (Kotler dan Keller, 2009:5). Asosiasi pemasaran Amerika dalam Kotler dan Keller (2009:5) mendefinisikan "pemasaran adalah fungsi organisasi dan serangkaian proses menciptakan, mengkomunikasikan dan memberikan nilai kepada pelanggan dan untuk mengelola hubungan pelanggan dengan cara yang menguntungkan organisasi dan pemangku kepentingannya".

Surachman (2010:1) berpendapat bahwa "Pemasaran adalah ujung tombak dari kegiatan bisnis yang dilakukan oleh organisasi atau perusahaan, terutama perusahaan yang memiliki tujuan untuk mendapatkan keuntungan, meningkatkan volume penjualan, memungkinkan pertumbuhan, memiliki pangsa pasar dan untuk menciptakan pelanggan setia".

Kotler dan Keller (2009:9) berpendapat bahwa terdapat jenis entitas dalam ilmu pemasaran, yaitu:
a. Baranng.
b. Jaasa.
c. Penggayaan peengalaman.
d. Perisstiwa
e. Oraang.
f. Temmpat.
g. Properrti.
h. Orgganisasi.
i. Innformasi.
j. Gaggasan.

Manajeemen pemmasaran adalah "proses menganalisis, merencanakan, dan mengendalikan program-program yang mencakup pengkonsepan, penetapan harga, promosi dan distribusi dari produk, jasa dan gagasan yang dirancang untuk menciptakan dan memelihara pertukaran yang menguntungkan dengan pasar sasaran untuk mencapai tujuan perusahaan" (www.innfo-maanajemen.com).

Daryanto (2011:1) dalam bukunya mengungkapkan bahwa yang dimaksud dengan marketing ialah "suatu proses sosial dan manajerial dimana individu dan kelompok mendapatkan kebutuhan dan keinginan mereka dengan menciptakan, menawarkan, dan 
JURNAL

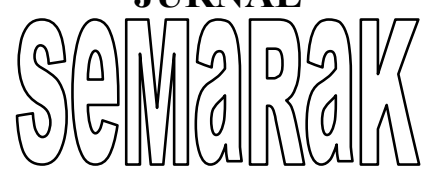

Semarak,Vol. 1, No.3,Oktober 2018, Hal (1-20)

@Prodi Manajemen Fakultas Ekonomi Universitas Pamulang

bertukar sesuatu yang bernilai satu sama lain".

Alma (2011:1) memperkuat pengertian markerting ialah "kegiatan memasarkan barang tidak berarti hanya menawarkan barang atau menjual tetapi lebih dari itu. Yang dimana terdapat kegiatan membeli, menjual dengan segala macam cara yang menyangkut barang, menyimpan dan mensortir".

Dapat dijelaskan bahwa tujuan dari sistem marketing merupakan "memaksimumkan konsumsi, memaksimumkan kepuasan konsumsi, memaksimumkan pilihan, memaksimumkan mutu hidup, serta meningkatkan kualitas, kuantitas, ketersediaan, harga, dan memperoleh laba bagi perusahaan. Tujuan pemasaran dapat tercipta dengan melakukan analisa dalam hal bauran pemasara (marketing mix), marketing mix merupakan seperangkat alat pemasaran yang digunakan perusahaan untuk terus menerus mencapai tujuan pemasaranya di pasar sasaran" (Kotler, 2009:101).

\section{Pengertian Manajemen Pemasaran}

Pemasaran dan pengeluaran adalah fungsi utama bagi syarikat. Semua syarikat cuba menghasilkan dan memasarkan produk atau perkhidmatan untuk memenuhi keperluan pengguna. Pada masa ini aktiviti pemasaran mempunyai peranan yang sangat penting dalam dunia perniagaan. Kadang-kadang istilah pemasaran ini ditafsirkan sama seperti beberapa istilah, seperti: jualan, perdagangan dan pengedaran. Pemasaran adalah konsep yang komprehensif, manakala istilah lain hanya satu bahagian, satu aktiviti dalam sistem pemasaran secara keseluruhan, jadi pemasaran adalah keseluruhan pengertian penjualan, perdagangan dan pengedaran (Swastha, 2010:178).

Swastha (2010:191) menyatakan bahwa pasaran adalah orang yang mempunyai keinginan untuk berpuas hati, wang untuk membeli-belah dan kesediaan untuk dibelanjakan. Daripada definisi ini boleh diketahui di pasaran terdapat 3 elemen penting, yaitu, orang dengan semua keinginan, daya beli mereka dan kesanggupan untuk menghabiskan uang mereka.

Kotler dan Keller (2012:6) berpendapat dalam bukunya bahwa "Pemasaran berhubungan dengan mengidentifikasi dan memenuhi kebutuhan masyarakat". Salah satu dari definisi pemasaran terpendek adalah untuk memenuhi kebutuhan secara menguntungkan. Menurut Asosisasi pemasaran Amerika dalam Kotler, pemasaran merupakan satu fungsi organisasi dan seperangkat proses yang bermanfaat untuk menciptakan, mengomunikasikan dan menyerahkan 
JURNAL

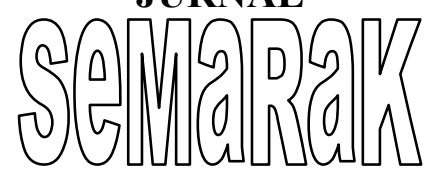

P-ISSN 2615-6849 E-ISSN 2622-3686

Semarak,Vol. 1, No.3,Oktober 2018, Hal (1-20)

@ Prodi Manajemen Fakultas Ekonomi Universitas Pamulang nilai kepada pelanggan dan mengelola hubungan pelanggan dengan cara yang menguntungkan organisasi dan para pemilik sahamnya. "Manajemen pemasaran merupakan seni dan ilmu memilih pasar sasaran dan mendapatkan, menjaga dan menumbuhkan pelanggan dengan menciptakan, menyerahkan dan mengkomunikasikan nilai pelanggan.

Manajemen pemasaran merupakan "seni dan ilmu memilih pasar sasaran dan mendapatkan, menjaga, dan menumbuhkan pelanggan dengan menciptakan, menyerahkan dan mengkomunikasikan nilai pelanggan yang unggul" (Kotler dan Keller, 2012:6).

\section{B. Bauran Pemmasaran}

Menurut Kotler (2009:12) "pemasaran memiliki fungsi yang sangat penting dalam mencapai kesuksesan perusahaan. Dalam mencapai kesuksesan Pemasaran, setiap perusahaan perlu mengembangkan strategi pemasaran yang efektif dengan menggabungkan unsurunsur dalam bauran pemasaran. Dalam Marketing Mix ada variabel yang saling mendukung satu sama lain yang kemudian digabungkan oleh perusahaan untuk memperoleh tanggapan yang diinginkan di pasar sasaran. Dengan perangkat ini, perusahaan dapat memengaruhi permintaan untuk produknya". Markeeting mix merupakan "kombinasi dari empat variabel atau kegiatan yang merupakan inti dari sistem pemasaran perusahaan yakni, produk, struktur harga, kegiatan promosi dan sistem distribusi" (Swastha, 2010:193).

Marketing mix tersebut merupakan "satu perangkat yang menentukan tingkat keberhasilan pemasaran bagi perusahaan dan semua ini ditujukan untuk memberikan kepuasan pada segmen pasar atau konsumen yang dipilih" (swastha, 2010:193).

Campuran pemasaran atau campuran pemasaran adalah gabungan empat pembolehubah, iaitu produk, struktur harga, aktiviti promosi, dan sistem pengedaran (Dharmmesta dan Handoko, 2000: 124). Empat elemen campuran pemasaran saling berkaitan dan mempengaruhi antara satu sama lain, jadi ia harus dicari untuk menghasilkan dasar pemasaran yang membawa kepada perkhidmatan yang berkesan dan kepuasan pelanggan. Oleh itu, dalam Mix Marketing ada pembolehubah yang menyokong antara satu sama lain, yang kemudian digabungkan oleh syarikat untuk mendapatkan respons yang diinginkan di pasaran sasaran. Dengan peranti ini, syarikat boleh mempengaruhi permintaan terhadap produknya. Dalam menjalankan strategi pemasaran, syarikat boleh menggabungkan elemen terkawal yang 


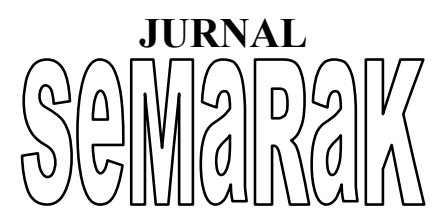

P-ISSN 2615-6849 E-ISSN 2622-3686

Semarak,Vol. 1, No.3,Oktober 2018, Hal (1-20)

@Prodi Manajemen Fakultas Ekonomi Universitas Pamulang dikenali sebagai campuran pemasaran (Kotler dan Amstrong, 2003:78). Adapun bauran pemasaran dibagi kedalam 4 (empat) kelompok yang terkenal, yaitu ||4P || yang terdiri dari:

\section{Prodduk (Producct)}

Prroduk adalah "barangan dan perkhidmatan yang ditawarkan oleh syarikat-syarikat pasaran yang boleh dinikmati, digunakan atau dimakan oleh pengguna kemudian. Produk ini adalah harta yang bersifat intangible dan tidak ketara termasuk pembungkusan, warna, harga, prestij syarikat dan peruncit, perkhidmatan syarikat dan peruncit yang diterima oleh pembeli untuk memenuhi keinginan" (swastha, 2010: 194).

2. Harrga (Price)

Yang dimaksud dengan harga "jumlah (wang) yang mesti dibayar untuk mendapatkan barangan atau perkhidmatan yang diperlukan. Harga adalah satu-satunya penyelesaian campuran pemasaran yang menyediakan pendapatan atau pendapatan bagi syarikat, sementara tiga elemen lagi produk, pengedaran dan promosi memerlukan perbelanjaan dana. Di samping itu, harga boleh berubah dengan pantas mengikut pasaran" (Tjiptono, 2008:151).

3. Tempat (Place)
Yang dimaksud dengan tempat merupakan "menyediakan prodak keepada pengguna di tempat yaang betul, kualiti yang betul dan jumlah yang betul. Pengedaran adalah aktiviti syarikat yang menjadikan produk tersedia untuk menargetkan pengguna. Tempat ini juga mempunyai elemen termasuk: saluran, liputan, lokasi, ketersediaan dan pengangkutan. Pengedaran boleh ditafsirkan sebagai aktiviti pemasaran yang bertujuan untuk menyelaraskan dan memudahkan penyampaian barangan dan perkhidmatan dari pengeluar kepada pengguna supaya penggunaannya seperti diperkenalkan. (jenis, jumlah, harga, tempat dan bila diperlukan) (Tjipptono, 2000:185).

\section{Promosi (Promotion)}

Promosi adalah "aktiviti untuk mengambil lebih banyak produk dan memujuk pengguna untuk membelinya. Promosi adalah aktiviti yang dijalankan /oleh syarikat untuk dapat berkomunikasi lebih dan dapat mempromosikan produknya lagi ke pasaran sasaran" (Kottler, 2000:39).

\section{Atrribut Prooduk}

Pendapat Kottler dan Armmstrong (2001:354) yang menjadi karakteristik dari atriibut prodduk ialah:

1. Merek (branding)

Merk (brand) merupakan "nama produk, pengertian, lambang, logo, 
JURNAL

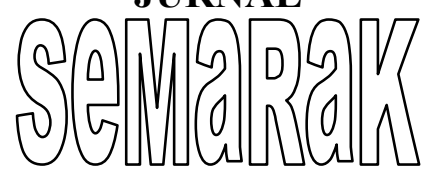

Semarak,Vol. 1, No.3,Oktober 2018, Hal (1-20)

@Prodi Manajemen Fakultas Ekonomi Universitas Pamulang

atau reka bentuk, atau gabungan dari kesemuanya yang dimaksudkan untuk mengenal pasti produk atau perkhidmatan daripada satu atau sekumpulan penjual dan membezakannya daripada produk yang bersaing. Penjenamaan adalah masalah utama dalam strategi produk. Penjenamaan adalah mahal dan memakan masa, dan boleh membuat produk berjaya atau gagal. Nama jenama yang baik boleh menambah kejayaan besar kepada produk" (Kottler dan Armmstrong, 2001:360).

2. Pengemmasan (paccking)

Pengemasaan (pakcking) ialah "aktiviti merancang dan membuat bekas atau pembungkusan produk".

Kualiti Prodak Kualiti Prodak merupakan "keupayaan produk untuk menjalankan fungsinya termasuk keboleh percayaan, ketahanan, kemudahan pengendalian dan pembaikan, dan sifat-sifat berharga yang lain". Untuk meningkatkan kualiti produk, syarikat boleh melaksanakan program "Total Quality Management (TQM)". Selain mengurangkan kerosakan produk, matlamat utama kualiti adalah untuk meningkatkan nilai pelanggan.

\section{Hargga (Price)}

Harga ialah "satu-satunya ukuran campuran pemasaran yang menyediakan pendapatan atau pendapatan bagi syarikat, manakala tiga elemen lagi produk, pengedaran dan promosi memerlukan perbelanjaan dana. Di samping itu, harga boleh berubah dengan pantas mengikut harga pasaran" (Tjiptono, 2008:151).

\section{Promosi}

Promosi adalah "jenis komunikasi yang memberikan penjelasan yang meyakinkan bakal pelanggan mengenai barang dan perkhidmatan Tujuan promosi adalah untuk mendapatkan perhatian, mendidik, mengingatkan dan meyakinkan bakal pelanggan. Promosi adalah perniagaan yang dijalankan oleh pemasar, berkomunikasi dengan bakal pelanggan, sedangkan komunikasi adalah proses membagi idea, maklumat, atau perasaan pengguna" (Allma, 2007:179).

Kotler (2009:15) berpendapat bahwa promosi adalah "percubaan oleh pemasar untuk memaklumkan dan mempengaruhi orang atau pihak lain agar mereka berminat membuat transaksi atau bertukar produk untuk barang atau perkhidmatan yang mereka pasaran”.

\section{E. Varieety Seekking}

Tingkah laku mencari variasi (pelbagai - tingkah laku mencari) adalah fenomena yang menarik minat dan perhatian akademik dan pengamal pemasaran, terutamanya dalam bidang tingkah laku pengguna. Sekurang- 


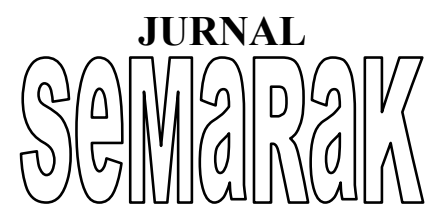

P-ISSN 2615-6849 E-ISSN 2622-3686

Semarak,Vol. 1, No.3,Oktober 2018, Hal (1-20)

@ Prodi Manajemen Fakultas Ekonomi Universitas Pamulang kurangnya minat itu berdasarkan dua faktor utama. Pertama, tingkah laku semacam ini boleh menjadi tingkah laku yang tidak sengaja, seperti perilaku pembelian penerokaan, penerokaan pengganti dan penggunaan inovatif. Tingkah laku semacam ini boleh dijelaskan lebih lanjut oleh motif hedonik atau pengalaman daripada aspek penggunaan utilitarian produk. Kedua, tingkah laku carian variasi adalah salah satu penentu penukaran jenama, begitu banyak syarikat berminat untuk memahami corak pembelian pelanggan (Alma, 2007:207).

\section{Pengguna sering menyatakan} kepuasan dengan jenama barangan seperti yang mereka gunakan sekarang, tetapi masih terlibat dalam penggantian jenama. Ini boleh berlaku kerana mencari variasi adalah motif pengguna yang lazim. Pengguna yang mempunyai penglibatan emosi yang rendah dalam jenama mudah bergerak ke jenama yang bersaing. Trend ini sering menjadi kebimbangan pemasar untuk kejayaan produk yang ditawarkan. Cari variasi akan berlaku jika tahap penglibatan pengguna dalam jenama adalah rendah dan pengguna menyedari perbezaan antara jenama (Assael, 1984) dalam (Hafizha, 2010:21).

\section{F. Brannd Swiitching}

Banyak perkara yang menyebabkan pengguna melakukan menukar atau menukar jenama jenama termasuk perubahan yang berlaku dari sisi pengguna (dalaman) dan rangsangan pemasaran (luaran). Pengguna menerima maklumat pasif apabila pengguna melihat iklan di televisyen, akhbar, majalah, dan media luar seperti sepanduk, sepanduk, papan iklan dan lain-lain. Promosi pengiklanan (peringatan pengiklanan) mencipta kebiasaan jenama dan bukan keyakinan jenama. Oleh itu, pemasar mesti mempunyai pengetahuan berhati-hati mengenai tingkah laku pengguna kerana pemasar tidak dapat meramalkan apa yang ada dalam fikiran seseorang ketika membeli produk atau tahu apa yang pengguna inginkan atau perlu. Anjakan jenama adalah tingkah laku pengguna yang mencerminkan perubahan produk jenama yang lazim digunakan dengan produk jenama lain. (Chatrin, 2007: 6).

Berdasarkan definisi ini, dijelaskan bahawa pensuisan merek ialah di mana konsumen atau kumpulan konsumer bergerak loyality dari satu jenama ke produk tertentu ke jenama produk lain. Satu lagi definisi switching jenama adalah penukaran jenama yang dijalankan oleh pelanggan untuk setiap masa penggunaan, tahap penukaran jenama ini juga menunjukkan sejauh mana jenama memiliki konsumer yang loyal (Ribhhan, 2006:99). Menurut Billson Simmamora (2004:22) menjelaskan bahawa konsumen yang sering membuat pertukaran jenama 


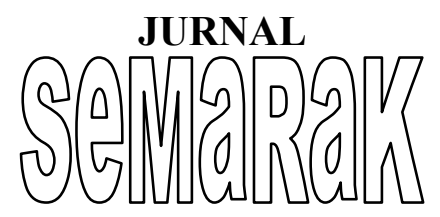

P-ISSN 2615-6849 E-ISSN 2622-3686

Semarak,Vol. 1, No.3,Oktober 2018, Hal (1-20)

@Prodi Manajemen Fakultas Ekonomi Universitas Pamulang dalam pembelian mereka termasuk dalam jenis tingkah laku belanja yang mencari kepelbagaian (Variasi Mencari Perilaku Membeli). Penukaran jenama dicirikan oleh perbezaan yang signifikan antara jenama.

\section{G. Hipotesis Penelitian}

Menurut rangka kerja di atas selaras dengan objektif kajian untuk menjawab soalan penyelidikan, hipotesis yang diuji adalah seperti berikut:

1. $\mathrm{H}_{\mathrm{o}}$ : Produk, promosi dan Pelbagai Mencari pembolehubah sifat tidak mempunyai kesan penting separa pada penukaran jenama.

$\mathrm{H}_{\mathrm{a}}$ : Atribut produk, promosi dan Variasi Mencari pembolehubah sebahagiannya mempunyai kesan yang ketara pada penukaran jenama.

2. $\mathrm{H}_{\mathrm{o}}$ : Atribut produk, promosi dan Variasi Mencari pembolehubah tidak mempunyai kesan yang signifikan secara serentak pada jenama switchingg.

$\mathrm{H}_{\mathrm{a}}$ : Pembolehubah produk, promosi dan Variasi Mencari sifat mempunyai kesan serentak yang ketara pada pensuisan jenama.

\section{METODDE PEENELITIAN}

Lokasi dalam kajian ini adalah kawasan Serpong. Metoda yang akan dipakai dalam analisis ini merupakan metoda kajian kes yang menajdi satu kajian deskriptif, dengan kajian ini dijangka akan mendedahkan secara mendalam pembolehubah yang akan dapat menggambarkan analisis sifat-sifat produk, promosi dan variasi mencari penukaran merek.

Angka / data yang dipakai menggunakan angka primer dan angka sekunnder. Data prrimer dalam bentuk wawancara berganda dan dalam bentuk soal selidik sementara data sekunder dalam bentuk benda umum benda penyelidikan (PT Indosat).

Teknik pensampelan yang akan diambil dalam kajian ini adalah kemudahan pensampelan, yang merupakan istilah umum yang merangkumi pelbagai prosedur untuk memilih responden. Pensampelan kemudahan bermaksud unit sampel yang diambil mudah untuk dihubungi, tidak menyusahkan, mudah diukur, dan koperasi. Bagi saiz sampel penyelidikan mengikut Roscoe dalam kaedah penyelidikan buku untuk perniagaan (Sugiyono, 2010: 52) menyatakan bahawa saiz sampel yang boleh dilaksanakan dalam kajian adalah antara 30 dan 500. Dalam kajian ini, penyelidik menggunakan sampel sebanyak 60 responden.

Teknik pengumpulan data menggunakan temubual dan pemerhatian dan soal selidik. Sampel yang digunakan 


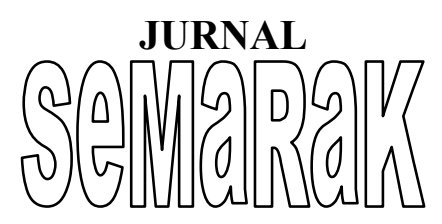

sebagai objek kajian ialah 60 orang pengguna di kawasan Serpong.

\section{HASIIL DDAN PEMMBAHASAN}

\section{A. Gambbaran Umuum PT. Inndosat}

Indosat (lengkap PT Indosat Tbk.)

Adalah salah satu syarikat yang menyediakan perkhidmatan telekomunikasi dan rangkaian telekomunikasi di Indonesia. Syarikat menawarkan saluran komunikasi untuk pengguna mudah alih dengan pilihan prabayar dan pascabayar dengan jenama yang menjual Matrix, Mentari dan IM3; Perkhidmatan lain yang disediakan adalah komunikasi melalui saluran suara untuk telefon tetap termasuk sambungan langsung antarabangsa antarabangsa, IDD (International Direct Dialing) dan perkhidmatan tanpa wayar dengan tanda dagangan StarOne. Syarikat juga menyediakan perkhidmatan multimedia, internet dan komunikasi data (MIDI = Multimedia, Internet dan Data (Perkhidmatan Komunikasi).

Pada tahun 2011 syarikat itu menguasai 21 peratus pasaran saham dan pada 2013 mengaku mempunyai 58.5 juta pelanggan untuk telefon bimbit. Tapak pelaburan untuk Indonesia menyatakan bahawa Indosat kehilangan beberapa peratus dari pasaran pelanggannya pada tahun lalu. Sementara laman web lain (Onbile.com) menempatkan Indosat sebagai syarikat telekomunikasi terbesar ketiga.

\section{B. Penemmuan dan Pembbahasan}

\section{Hasil Ujji Valliditas daan Reaabilitas}

Kesahan didefinisikan sebagai sejauh mana ketepatan dan kecermatan suatu alat ukur dalam melakukan fungsi ukurannya. Pengertian sah tidaknya suatu alat ukur bergantung kemampuan alat tersebut untuk mengukur objek yang diukur dengan teliti dan tepat. Keputusan pada sebuah butir pertannyaan boleh dianggap sah.

Sedangkan keboleh percayaan pada dasarnya adalah sejauh mana hasil suatu pengukuran boleh dipercayai. Jika hasil pengukuran yang dilakukan berulang menghasilkan hasil yang relatif sama, ukuran tersebut dianggap mempunyai tahap kebolehpercayaan yang baik. Menurut Bhuno, (2005: 72) uji kebolehpercayaan dilakukan dengan melihat nilai Cronbach 's Alpha, Jika nilai Cronbach' s Alpha $>0.6$ maka suatu instrumen dikatakan reliabel, jika nilai Cronbach 's Alpha $<0.6$ maka suatu instrumen dikatakan tidak reliabel Untuk mendapatkan data primer, penulis melakukan penyebaran soal selidik kepada responden pada sebanyak 60 responden. Sebelum soal selidik disebarkan kepada 60 responden, penulis melakukan try out kepada 20 ressponden denngan 
JURNAL

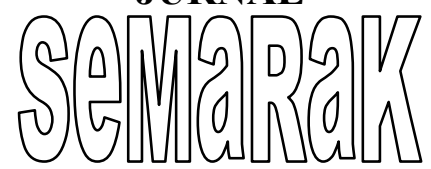

Semarak,Vol. 1, No.3,Oktober 2018, Hal (1-20)

@.Prodi Manajemen Fakultas Ekonomi Universitas Pamulang

meemberikan 37 buttir pertannyaan.

Berikut ini adalah hasil try out yang diberikan kepada 20 ressponden dengaan 37 butir sooalan yang dibahagaikan menjadi 4 pembolehubah utama iaitu atribut produuk, prommosi, varietyy seekking dan braand switching.

Tabel 1

Hasil Uji Validitas Variabel Kualitas Produk $\left(X_{1}\right)$

\begin{tabular}{|c|c|c|c|c|}
\hline $\begin{array}{c}\text { Den } \\
\text { retresas }\end{array}$ & $\begin{array}{l}\text { Camsin' } \\
\text { Ane-Tise } \\
\text { Cermatike }\end{array}$ & Kribramai & coulanst & Niseranza \\
\hline \multicolumn{5}{|c|}{ Antiket Protak $\left|x_{1}\right\rangle$} \\
\hline shi & ropts & vais & nexs & Returyi \\
\hline or & 6,00 & Vuis & wol & RALIFI \\
\hline$A r 3$ & 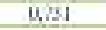 & valu & $10 \times 5$ & Bolbatel \\
\hline ari & 15,14 & veli & 10s\% & Roturel \\
\hline APs & as: & vali & 1096 & Rulithy \\
\hline ifi & 100 & vali & nome & RHWhel \\
\hline ar & Wov: & Vall & wese & Retherel \\
\hline An & whiz & Vall & us!l & Kolbial \\
\hline Art & 6,423 & vali & 16 sib & Rolthel \\
\hline APio & 574 & valit & $110 \times 5$ & Botluhei \\
\hline \multicolumn{5}{|l|}{ Prover $\mathbf{X}_{j}$} \\
\hline $\mathrm{mut}$ & 1.84 & vidi & es: & Returel \\
\hline FU12 & Wo: : & valu & Useo & Ddbetal \\
\hline FNB & weo & Vald & 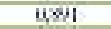 & Bdtbel \\
\hline PMI & gixt & vald & Q.5ii & Butiubl \\
\hline rus & 604 & vali & 620 & Rolubl \\
\hline $\mathrm{rWh}$ & 621. & vilu & esso & Nottaki \\
\hline FM? & wow & vilit & us: & M.tblel \\
\hline \multicolumn{5}{|c|}{ havkt Swhieg (X) } \\
\hline visi & 4.21 & valu & 11042 & Rotluhal \\
\hline 15: & 0.76 & vild & 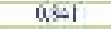 & Bullubl \\
\hline 453 & Wes & vilit & $\theta \leq 00$ & Kottaxl \\
\hline vS4 & 0,516 & Tuld & Usic & Kottats \\
\hline vss & U.508 & Volla & $\omega \infty \bar{i}$ & R.tbial \\
\hline vsi & 6,291 & vali & $10 \leq 3$ & Boltuhal \\
\hline vs? & 05 & valit & asi & Bottubi \\
\hline \multicolumn{5}{|c|}{ Bzwisantive |Y| } \\
\hline BSI & 6,56 & ivit & $0=0$ & N.tidel \\
\hline Es: & $6 x=$ & velit & 1915 & Ndblat \\
\hline DS3 & 15,4t & Yvid & gyis & Bdbloke1 \\
\hline DSA & $5, w$ & veld & 15016: & Ritichel \\
\hline nas & Dan & valit & 110" & Rutioni \\
\hline BS3 & $0,0<$ & Yaid & 0,2 & K.thix| \\
\hline Ex? & MII & Vali & $n=x$ & Ratikei \\
\hline BSS & wor & vids & U\%न & N.thel \\
\hline DS9 & 0.527 & Valld & (0913 & Retlabel \\
\hline ISS19 & $0, \$ 26$ & Valld & 0.914 & Retlabel \\
\hline
\end{tabular}

2. Hasil Ujji Assumsi Klaasik

a. Hasil Ujii Noormalitas Daata

Gambar 1

Hassil Ujii Normalitaas Dsata

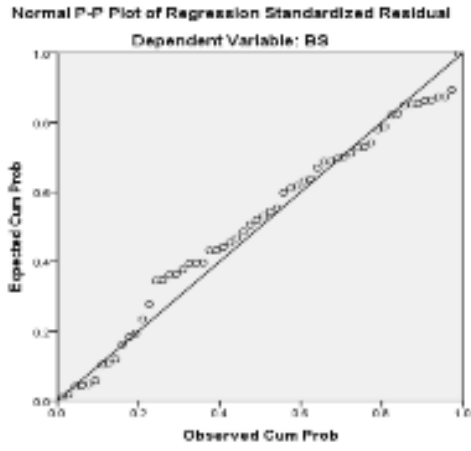

Dari graf pp plot, diperhatikan data peneltian memppunyai pengedaran dan pengedaran yang normal kerana data berpusat pada nilai purata dan median atau nilai plot PP terletak secara menyerong, jadi boleh dikatakan bahawa data diedarkan secara normal.

\section{b. Hasiil Uj Multikoolinearitas}

Tabel 2

Haasil Ujii Multikoolinearitas

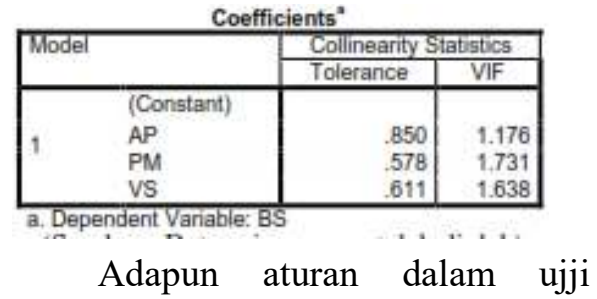
multikolineearitas adalah nilai VIF harus $<10$ dan nilai tolerance $>$ 0,10, hasil membuktikan bahwa tidak terjadi multikolinearitas karena nilai VIF lebih kecil dari 10 dan nilai tolerance di atas 0,10 .

c. Hasiil Ujii Heterooskedastisitas

Gambar 2

Hassil Ujii Heterooskedastisitas

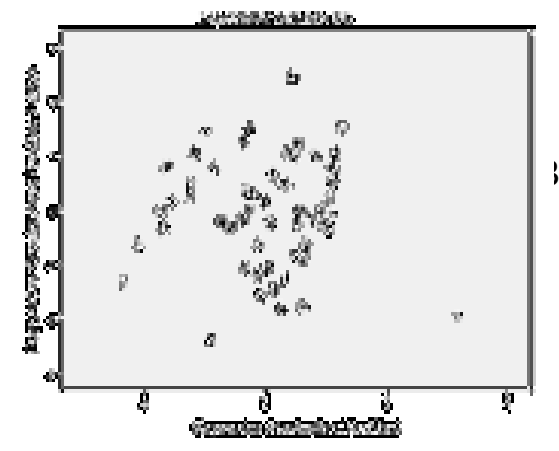


JURNAL

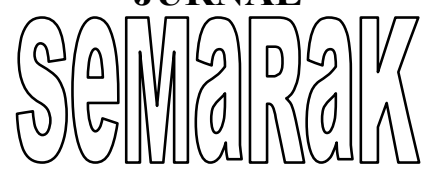

Semarak,Vol. 1, No.3,Oktober 2018, Hal (1-20)

@Prodi Manajemen Fakultas Ekonomi Universitas Pamulang

pembolehubah lain yang tidak diketahui dan tidak termasuk dalam analisis regresi ini, seperti imej jenama, kualiti perkhidmatan, kualiti produk.

Dalam gambar di atas, dapat dilihat bahawa mata yang tersebar di atas dan di bawah sifar pada paksi Y dan tidak ada corak tertentu. Oleh itu dalaam persammaan reegresi bergannda liinear dalam modeel iini tidak ada gejala atau tidak ada heteroscedasticity.

\section{Haasil Analiseis Koeffisien Rgegresi}

\section{Liniear Beraganda}

a. Haasil Koeefisien Deeterminasi (Uji Adjusted R ${ }^{2}$ )

Tabel 3

Haasil Koefisieen Deeterminasi (Adjusted $\mathbf{R}^{2}$ ) Model Summary"

\begin{tabular}{l|c|r|r|r|r|}
\hline Model & $R$ & RSquare & $\begin{array}{r}\text { Adjusted } \\
\text { R Square }\end{array}$ & $\begin{array}{c}\text { Std. Eror of the } \\
\text { Estimate }\end{array}$ & Durbin-Watison \\
\hline 1 & $.806^{2}$ & .650 & 631 & .25664 & 2.110 \\
\hline a. Predictors: (Constant), VS, AP, PM \\
b. Dependent Variable: BS
\end{tabular}

Berdasarkan jadual di atas, nilai yang diselaraskan $\mathrm{R}$ persegi adalah 0.631 (63.1\%), menunjukkan bahawa dengan menggunakan model regresi yang diperolehi di mana pembolehubah bebas iaitu atribut produk, promosi dan pencarian pelbagai mempunyai pengaruh terhadap penukaran jenama berubah sebanyak $63.1 \%$. Sementara baki $36.9 \%$ dijelaskan oleh faktor atau

\section{b. Hasiil Koefisieen Persaamaan Ujji} Regresi Liniear Beraganda

Analisis regresi linier berganda adalah ujian yang digunakan untuk menentukan berapa banyak pengaruh antara pembolehubah bebas (Atribut Produk, Promosi dan Pelbagai Mencari) pada pembolehubah yang bergantung kepada (Switching Jenama). Hasil pengaruh regresi linier berganda Atribut Produk, Promosi dan Pelbagai Mencari Pengubah Jenama adalah seperti berikut:

Tabel 4

Hasil Koeefisien Perrsamaan Reggresi Liinier Berrganda

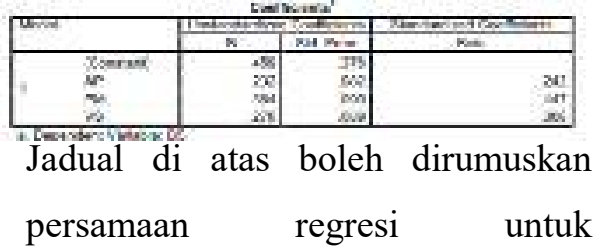
menentukan kesan atribut produk, promosi dan pencarian pelbagai ke arah menaip jenama seperti berikut:

$\mathrm{Y}=\mathrm{a}+\mathrm{bx} 1+\mathrm{bx} 2+\mathrm{bx}$ 
JURNAL

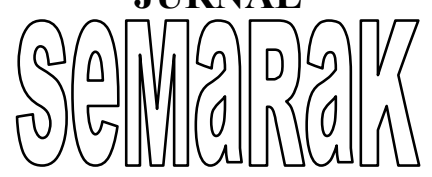

Semarak,Vol. 1, No.3,Oktober 2018, Hal (1-20)

@ Prodi Manajemen Fakultas Ekonomi Universitas Pamulang

$\mathrm{Y}=0,459+0,232 \mathrm{X}_{1}+0,384 \mathrm{X}_{2}+$ $0,270 \mathrm{X}_{3}$

Keterangan :

Y : Brannd Swittching

X1 : Atribbut Prooduk

X2 : Prommosi

X3 : Variiety Sekeking

Koefisien persamaan regresi linear berganda di atas boleh ditafsirkan sebagai pekali regresi malar 0.459 menunjukkan bahawa jika atribut, promosi dan variasi mencari jenis produk adalah sifar, nilai kepuasan pengguna ialah 0.459 unit atau $45.9 \%$. Perhatikan bahawa pembolehubah lain dianggap malar. Variabel atribut produk 0.232 menunjukkan bahawa jika pemboleh ubah atribut produk meningkat sebanyak 1 unit, ia akan meningkatkan penukaran jenama sebanyak 0.232 unit atau 23.2\% Variabel promosi $\quad 0.384$ menunjukkan bahawa jika kenaikan nilai promosi sebesar 1 unit, ia akan meningkatkan penukaran merek sebanyak 0.384 unit atau 38.4\%. Pemboleh ubah mencari variabel 0.270 menunjukkan bahawa jika variasi vaiabel mencari peningkatan sebanyak 1 unit maka ia akan meningkatkan penukaran jenama sebanyak 0.270 unit, dengan syarat pembolehubah lain dianggap tetap.

\section{Hasiil Ujji Hipootesis}

\section{a. Hasisl Uji Sttatistik F}

Ujian $F$ telah dijalankan untuk melihat kesan produk berubah-ubah, promosi dan pelbagai sifat mencari secara keseluruhan pada pemboleh ubah beralih jenama. Berikut adalah keputusan ujian serentak, keputusan ujian ANOVA diperolehi seperti berikut:

\section{Tabel 5}

Hasil Uji Statistik F (Simultan)

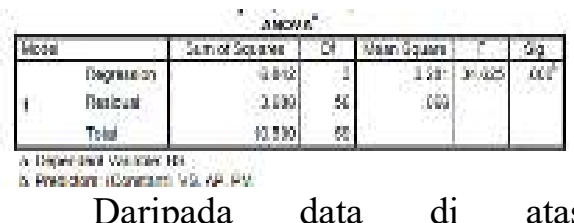
memperoleh nilai signifikan 0,000 bermakna bahawa peruntukan nombor dua terpakai dalam kajian ini yang Ho ditolak dan Ha diterima. Keputusan ujian $\mathrm{F}$ ini menyatakan bahawa keputusan ujian serentak di atas adalah benar.

Dalam kajian ini, nilai $F$ yang dikira adalah 34.625 yang lebih besar daripada nilai Ftable 2.77. Ini bermakna bahawa peruntukan nombor dua adalah benar. Sebagai kesimpulan, terdapat pengaruh linier antara variabel bebas dan pemboleh ubah yang bergantung.

\section{b. Hasil Ujii t (Ujii Seccara Paarsial)} Tabel 6 
JURNAL

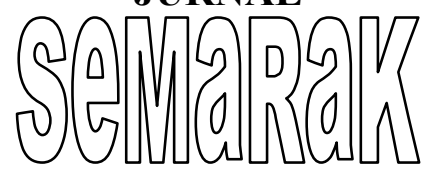

Semarak,Vol. 1, No.3,Oktober 2018, Hal (1-20)

@Prodi Manajemen Fakultas Ekonomi Universitas Pamulang

Haasil Ujji t (Ujii Secaara Parrsial)

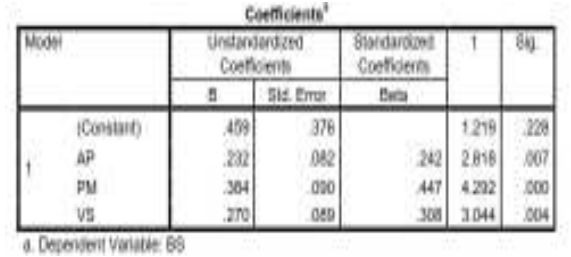

Berdasarkan keputusan ujian

t, dapat dilihat bahawa semua variable bebas sebahagiannya mempengaruhi pensuisan merek.

\section{KESIMMPULAN DAAN SARRAN}

\section{A. Kesimpuulan}

Kajian ini dijalankan untuk menentukan kesan atribut produk, promosi dan kepelbagaian yang dicari pada penukaran jenama. Berdasarkan hasil penyelidikan yang dijelaskan dalam bab sebelumnya, beberapa kesimpulan dapat diambil seperti berikut:

1. Hasil peneelitian mennyatakan bahhwa secaraa simmultan attau berdaasarkan hasil ujii $\mathrm{F}$ menunjuukkan bahwwa terdapaat pengaruuh siggnifikan antaara variablew atribuut prodduk, promoosi dan varieety seieking terhadap branndd switchiing.

2. Hasil kajian menyatakan bahawa sebahagian atau berdasarkan keputusan ujian $\mathrm{t}$ menunjukkan bahawa pembolehubah bebas yang mempengaruhi penukaran jenama adalah atribut produk, promosi dan pencarian pelbagai.

3. Hasil kajian menunjukkan bahawa berdasarkan uji penentuan bahawa terdapat pengaruh $63.1 \%$ antara pembolehubah atribut produk, promosi dan variasi yang mencari mempengaruhi penukaran merek.

\section{DAFTAR PUSTAKA}

Agarwal, S. dan Teas, R. K., "Perceives Value: Mediating Role of Perceived Risk”, Jurnal, 2001

Agung Nugroho, Bhuono. 2005. Strategi Jitu Memilih Metode Statistik Penelitian dengan SPSS. Yogyakarta: Penerbit Andi.

Alma, Buchari. (2007). Manajemen pemasaran dan pemasaran jasa. Bandung: Alfabeta.

Ansoft, Igor and Edward Mc. Donell, Implanting Strategic management, 2nd,Prentice hall Inc. 1992

Arikunto, S. 2002. Prosedur Suatu Penelitian: Pendekatan Praktek. Edisi Revisi Kelima. Penerbit Rineka Cipta. Jakarta

Assael, Henry, Marketing Management : strategy and action. Boston Massachussets : Kent Publishing, 1995

Basu Swastha, DH. Drs, M.B.A, Irawan Drs, M.B.A, 2000. Manajemen Pemasaran Modern. Yogyakarta : Liberty

Bhasin, Kamla dan Nighat Said Khan. 1995. Feminisme dan Relevansinya (diterjemah- kan oleh S. Herlinah). Jakarta: Gramedia Pustaka Utama.

Bilson, Simamora, 2004, Riset Pemasaran, Gramedia Utama, Jakarta.

Bilson Simamora.2004. Panduan Riset Perilaku Konsumen. Jakarta: PY. Gramedia Utama 


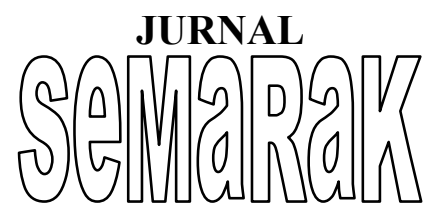

\section{P-ISSN 2615-6849 E-ISSN 2622-3686}

Semarak,Vol. 1, No.3,Oktober 2018, Hal (1-20)

@ Prodi Manajemen Fakultas Ekonomi Universitas Pamulang
Catherine A. Little , 2007.|| A Study of Curriculum Effectiveness in Social Studies\|. Gifted Child Quarterly Summer 2007 vol. 51 no. 3 272-284

E, Blech George and Michael, A. Blech (2007) advertising \& promotion : A, Imc perspecktive. McGraw Hill, New York

Fandy, Tjiptono. 2008. Strategi Pemasaran. Yogyakarta: Andi Offset.

Fandy Tjiptono, Manajemen Jasa, Penerbit Andi Yogyakarta 2000

Grewal \& Levy. 2008. Marketing. New York Mc- Graw Hill.

Husein Umar, 2003 Metode Riset Prilaku Organisasi, PT .Gramedia Pustaka Utama Jakarta.

Keaveney S, M. (1995) Customer switching behavior in service industries : an exploratory studi .journal of marketing, vol 59 april 7-82

Kotler, Philip. 2002. Manajemen Pemasaran, Analisa perencanaan, Implementasi dan control, Edisi Kesembilan, Jilid 1 dan jilid 2, Jakarta, Prehalindo, alih bahasa oleh Hendra Teguh S.E.,A.K., dan Ronny A. Rusli, S.E

, Marketing An Introduction (Eight Edition), New Jersey: Pearson Prentice Hall, 2000

, Marketing An Introduction (Eight Edition), New Jersey: Pearson Prentice Hall, 2001.

, Marketing An Introduction (Eight Edition), New Jersey: Pearson Prentice Hall, 2003

Marketing An Introduction (Eight Edition), New Jersey: Pearson Prentice Hall, 2007
, Marketing An Introduction (Eight Edition). New Jersey: Pearson Prentice Hall, 2006

Kotler, Philip. 2006. Manajemen Pemasaran Edisi 11. Jakarta: PT. Indeks

Kotler, keller (2009). Marketing 13 thn edisi. New Jersey : Printice Hall

Kotler P, \& Amstrong G (2004) —Principle of marketing $\|$ 10th edition Interntional, Prentice Hall, New Jersey

Kotler, Philip. 1997. Dasar-Dasar Pemasaran. Jakarta: Prenhalindo

Rangkuti, Freddy (2002), Measuring Customer Satisfaction Teknik Mengukur dan

Strategi Meningkatkan Kepuasan Pelanggan dan Analisis Kasus PLN-JP.PT. Gramedia Pustaka Utama, Jakarta

Ribhan, 2006. Faktor-faktor tang mempengaruhi Brand Swiching pada pengguna

SIM Carddi Fakultas Ekonomi Lampung. vol 3 no. 1 hal 34 - 56. JurnalBisnis dan manajemen.

Reichheld, Frederick F., 1996, The Loyalty Effect, Harvard Business School Press, Boston.

Sekaran, Uma. 2000. Research Methods for Business, A Akill-Building

Approach. America: Thirt Edition, John Wiley \& Sons, Inc.

Setiyaningrum, Ari. 2007. Pengaruh Ketidakpuasan Konsumen dan Variety Seeking terhadap Keputusan Perpindahan Merek. Jurnal Telaah Manajemen (TEMA), volume 2 No.2, Universitas Kristen Atmajaya (UNIKA), Yogyakarta. 
JURNAL

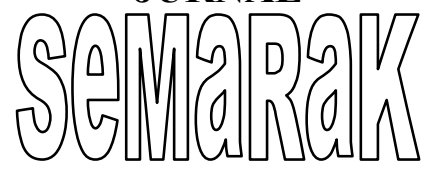

Singgih Santoso, 2004. Mengelola Data Statistic Secara Professional, PT. Elex Media Komputindo, Jakarta

Schiffman, Leon G. and Leslie Lazar Kanuk, 1997. Customer Behavior, USA:Prentice Hall Inc.

Soehardi, Sigit, Marketing Praktis, Edisi Ketujuh, Armurrita, Yogyakarta, 1992.

Stanton, wiliam, Fundamental of marketing (7 Edition), Mc.Graw Hill.Inc

Sugiyono. 2007. Metode Penelitian Kuantitatif Kualitatif dan R\&D\|. Bandung: Alfabeta

Swastha, Bashu, Ibnu Sukotjo, "pengantar Bisnis Modern”, Edisi Ketiga, Liberti, Yogyakarta, 2010. 